\title{
Pengaruh Perbandingan Daun Putri Malu (Mimosa pudica Linn.) dan Bunga Melati (Jasminum sambac (L.) Ait.) Terhadap Karakteristik Teh Celup Wangi
}

\section{The Effect of Comparison Mimosa pudica Linn. Leaves and Jasmine Flower (Jasminum sambac (L.) Ait.) on The Characteristics of Scented Tea Bag}

\author{
Michelle Olivia Isabella ${ }^{1}$, I Nengah Kencana Putra ${ }^{1 *}$, Gusti Ayu Kadek Diah Puspawati ${ }^{1}$ \\ Program Studi Teknologi Pangan, Fakultas Teknologi Pertanian, Universitas Udayana \\ Kampus Bukit Jimbaran, Badung-Bali \\ *Penulis korespondensi: I Nengah Kencana, Email: nengahkencana@unud.ac.id
}

\begin{abstract}
This study aimed to determine the effect of the comparison of Mimosa pudica L. leaves and jasmine on the characteristics of scented tea bag and find out the comparison of Mimosa pudica L. and jasmine to obtain the best characteristics of the scented tea bag. The experimental design used was Completely Randomized Design with the comparison treatment Mimosa pudica L. leaves and jasmine as a treatment which consist of 5 levels: 100\%:0\%, 85\%:15\%, 70\%:30\%, 55\%:45\%, and 40\%:60\%. The treatment was repeated three times, resulting in 15 experimental units. The data obtained then analyzed by the Analysis of Variance, and if the treatments had a significant effect, continued with the Duncan Multiple Range Test. The result showed that the comparison of Mimosa pudica Linn. and jasmine had significant effect on water content, water-soluble extractive, total phenol, total flavonoid, $\mathrm{IC}_{50}$ value, taste (scoring and hedonic test), aroma (scoring and hedonic test), and overall acceptance. The comparison of $70 \%$ Mimosa pudica L. and $30 \%$ jasmine had the best characteristic, which had a water content $10.97 \%$, water-soluble extractive $22.59 \%$, total phenol $3.70 \mathrm{mg}$ GAE/g, total flavonoids $1.05 \mathrm{mg}$ QE/g, IC 50 value $128.73 \mathrm{ppm}$. The brewed tea bag had a slightly liked color, a slightly liked and slightly jasmine aroma, a slightly bitter and slightly liked taste, and a slightly liked overall acceptance.
\end{abstract}

Keywords: jasmine, mimosa pudica linn leaves, scented tea bag

\section{PENDAHULUAN}

Putri malu (Mimosa pudica L.) adalah salah satu jenis tumbuhan yang merupakan suku Mimosaceae. Putri malu biasanya tumbuh di daerah bukit, hutan, rawa, dan tepi jalan di daerah Asia. Daun putri malu berbentuk kecil, tersusun secara majemuk, berbentuk lonjong serta letak daun berhadapan (Dalimartha, 2008).Hasil skrining fitokimia putri malu menunjukkan adanya kandungan senyawa kimia seperti alkaloid, fenol, steroid, flavonoid dan saponin (Pal et al., 2015). Menurut penelitian yang dilakukan Zhang (2011), dari seluruh bagian tanaman putri malu, daun putri malu mengandung senyawa flavonoid dan total fenol yang lebih tinggi dibandingkan bagian lainnya, yaitu total flavonoid sebesar $0,81 \mathrm{mg} / \mathrm{g}$, total fenol sebesar $9,87 \mathrm{mg} / \mathrm{g}$. Nilai $\mathrm{IC}_{50}$ ekstrak daun putri malu menggunakan metanol sebesar 126,71 $\mu \mathrm{g} / \mathrm{ml}$ (Das et al., 2014). Hasil tersebut menunjukkan bahwa daun putri malu memiliki potensi sebagai antioksidan.

Daun putri malu digunakan sebagai bahan obat tradisional di India. Berdasarkan pengobatan tradisional dari India (Siddha Medicine) pengolahan daun putri malu biasanya dilakukan dengan cara mengambil sari dari daun putri malu dan digunakan untuk mengobati berbagai macam penyakit (Varnika et al., 2012). Efek farmakologis yang dimiliki oleh daun putri malu yaitu anti radang, diuretik, anti-diabetes, anti depresan dan 
anti mikroba (Ahmad et al., 2012). Selain itu, uji toksisitas menunjukkan bahwa ekstrak herbal daun putri malu termasuk dalam kategori tidak toksik (Shahriar et al., 2014).

Selain mengambil sari dari daun putri malu peningkatkan pemanfaatan daun putri malu sebagai minuman fungsional dapat dilakukan diversifikasi menjadi teh herbal. Menurut Inti (2018), teh herbal merupakan hasil olahan teh yang tidak berasal dari daun teh Camellia sinensis. Bahan-bahan yang biasa digunakan untuk membuat teh herbal seperti daun, biji, akar, atau buah kering. Produk teh yang disukai oleh masyarakat merupakan produk yang praktis saat proses penyeduhannya. Teh celup merupakan produk olahan teh yang dikemas di dalam kemasan kantung dengan keunggulan yaitu cara penyajian yang praktis, rasa teh yang tetap terjaga, kebersihan dari hasil seduhan, serta hemat dalam jumlah pemakaiannya (Handayani, 2010).

Menurut Narasimhan et al., (2014) air infusi daun putri malu memiliki rasa pahit. Rasa pahit dari daun putri malu dikarenakan tanaman ini memiliki kandungan senyawa tanin yang biasanya memberikan rasa pahit pada tanaman tersebut. Selain itu, daun putri malu beraroma khas daun sehingga memiliki aroma off-flavour. Upaya untuk memperbaiki rasa dan aroma dari putri malu dapat dilakukan dengan penambahan bunga melati.

Terdapat dua spesies bunga melati yang sering ditemukan di Indonesia yaitu bunga melati putih (Jasminum sambac (L.) Ait) dan bunga melati gambir (Jasminum officinale). Bunga melati putih Jasminum sambac (L.) Ait. merupakan tumbuhan semak berbunga yang sangat dikenal luas karena keindahan serta memiliki aroma yang khas. Bunga melati putih adalah spesies melati yang sangat populer dan banyak digunakan sebagai pewangi teh karena memiliki aroma yang khas (Suyanti et al., 2004). Menurut Arifan et al., (2018), menambahkan bunga melati pada teh merupakan suatu keputusan yang baik dikarenakan menghasilkan aroma yang khas dari bunga melati dan juga memiliki banyak manfaat yang baik untuk kesehatan. Menurut penelitian yang dilakukan oleh Kunhachan et al., (2012) bunga melati mengandung flavonoid, fenol, saponin, minyak asiri, dan sebagainya. Selain itu, bunga melati juga memiliki senyawa pemberi aroma yaitu z-jasmone, indol, neurolidol, linalool, indol, dan benzil benzoat (Ray et al., 2016).

Berdasarkan penelitian yang dilakukan oleh Tahir (2017), perbandingan bunga melati sebesar $25 \%, 50 \%$ dan $75 \%$ terhadap berpengaruh terhdap aktivitas antioksidan dan karakteristik sensori minuman fungsional daun sukun, konsentrasi $25 \%$ bunga melati mampu meningkatkan daya terima panelis terhadap aroma dari produk. Penelitian mengenai perbandingan bunga melati dan daun putri malu belum dilakukan sebelumnya. Berdasarkan hal tersebut, perlu dilakukan analisis perbandingan bunga melati dan daun putri malu terhadap karakteristik teh celup wangi.

\section{METODE PENELITIAN}

\section{Bahan dan Alat}

Bahan yang digunakan dalam penelitian ini adalah daun putri malu (Mimosa pudica Linn.) muda dan segar dengan kriteria berwarna hijau muda yang didapatkan dari daerah Denpasar. Bunga melati putih (Jasminum sambac Ait.) 
dengan kriteria belum mekar yang didapatkan dari daerah Denpasar. Bahan kimia yang digunakan antara lain : aquades, metanol, DPPH (2,2diphenyl-1-picrylhydrazil) merk HIMEDIA, reagen Folin-Ciocalteu, sodium karbonat, asam galat, $\mathrm{Na}_{2} \mathrm{CO}_{3}, \mathrm{AlCl}_{3} \cdot 6 \mathrm{H}_{2} \mathrm{O}$, standar kuersetin, kertas saring Whatman no 1, aluminium foil, kertas label dan kantung teh.

Alat yang digunakan dalam penelitian ini adalah cawan porselin, labu ukur, gelas beker, gelas ukur, erlenmeyer, tabung reaksi, pipet tetes, blender, rotary shaker (H-MSR Health), spektrofotometer UV-VIS (Genesys 10S Uv-Vis), mikropipet, desikator, oven, loyang, pisau, aluminium foil, pinset, timbangan analitik (Shimadzu ATY224), cawan aluminium, kuvet, tips, vortex, ayakan 40 mesh, gelas untuk uji sensoris.

\section{Rancangan Percobaan}

Rancangan yang digunakan pada penelitian ini adalah Rancangan Acak Lengkap (RAL) dengan perlakuan perbandingan daun putri malu dan bunga melati yang terdiri dari 5 taraf perlakuan yaitu: $\mathrm{P} 0=100 \%: 0 \% ; \mathrm{P} 1=85 \%: 15 \% ; \mathrm{P} 2=70 \%$ : 30\%; P3 = 55\%: 45\%; P4 = 40\%: 60\%. Masingmasing taraf perlakuan diulang sebanyak tiga kali sehingga diperoleh 15 unit percobaan. Data yang diperoleh dianalisis dengan menggunakan sidik ragam dengan selang kepercayaan 95\% dan apabila perlakuan berpengaruh terhadap variabel yang diamati maka dilanjutkan dengan uji Duncan's Multiple Range (DMRT).

\section{Pelaksanaan Penelitian}

\section{Pembuatan Teh Celup Wangi Daun Putri Malu}

Daun putri malu segar disortasi, setelah itu dicuci dan dilakukan proses trimming. Proses trimming dilakukan untuk menghilangkan bagian yang tidak dikehendaki pada bahan. Bahan yang tidak dikehendaki pada proses pembuatan teh wangi ini adalah batang putri malu. Setelah proses trimming, dilakukan proses pelayuan menggunakan metode steaming (suhu $100^{\circ} \mathrm{C}$ selama 90 detik) (Topuz et al., 2014). Daun yang sudah mengalami proses pelayuan selanjutnya didinginkan \pm 5 menit. Kemudian, dikeringkan menggunakan oven dengan suhu $50^{\circ} \mathrm{C}$ dengan waktu 150 menit. Proses selanjutnya adalah pencampuran daun putri malu dan bunga melati dengan perbandingan sesuai perlakuan. Daun putri malu kering dan bunga melati dicampur hingga merata dan dilakukan proses pewangian selama 14 jam, dengan pengadukan tiap 3 jam sekali untuk meratakan proses pewangian. Proses pewangian ini dilakukan malam hari dimulai dari pukul 18.00 hingga pukul 08.00 keesokan harinya. Setelah itu, dilakukan pengeringan tahap kedua, yaitu daun putri malu dan bunga melati dikeringkan kembali pada suhu $50^{\circ} \mathrm{C}$ selama 30 menit (Setyamidjaja, 2000). Setelah diperoleh campuran daun putri malu dan bunga melati dilanjutkan dengan penghancuran menggunakan blender. Dilakukan pengayakan menggunakan ayakan 40 mesh. Bubuk teh wangi yang dihasilkan dikemas dengan menggunakan kantong teh celup sebanyak 2 gram.

\section{Proses Pembuatan Filtrat Teh Celup Wangi Daun Putri Malu}

Pembuatan filtrat digunakan untuk analisis total fenol, total flavonoid, dan aktivitas antioksidan. Sebanyak 1 gram bubuk teh celup wangi dilarutkan dengan $50 \mathrm{ml}$ metanol $80 \%$, kemudian di-shaker dengan menggunakan rotary shaker selama 1 jam pada suhu ruang. Selanjutnya, 
sampel disaring dengan menggunakan kertas saring Whatman no 1. Filtrat yang dihasilkan dimasukan ke dalam botol dan disimpan di dalam freezer (Ghasemzadeh et al., 2012).

\section{Pembuatan Seduhan Teh Celup Wangi Daun Putri Malu}

Satu kantung teh celup berisi 2 gram bubuk teh celup wangi kemudian diseduh dengan cara dicelup dalam $150 \mathrm{ml}$ air dengan suhu $80^{\circ} \mathrm{C}$ selama 2-3 menit (Badan Standar Nasional, 1996). Setelah itu, kantung teh celup dikeluarkan dari seduhan.

\section{Parameter yang diamati}

Parameter yang diamati dalam penelitian ini meliputi kadar air, kadar ekstrak dalam air, total fenol, total flavonoid, aktivitas antioksidan berdasarkan nilai $\mathrm{IC}_{50}$, uji sensoris (hedonik dan skoring). Bubuk teh celup wangi daun putri malu digunakan untuk menguji kadar air dengan metode oven (AOAC, 2005) dan analisis kadar ekstrak dalam air yang dilakukan menurut SNI 4324:2014. Filtrat teh celup wangi daun putri malu digunakan untuk menguji total fenol dengan metode FolinCiocalteu (Sakanaka et al., 2003), total flavonoid menggunakan metode Spektrofotometri UV-Vis (Rahman et al., 2006) dan aktivitas antioksidan berdasarkan nilai $\mathrm{IC}_{50}$ menggunakan metode DPPH (Hanani et al., 2005). Seduhan teh celup wangi daun putri malu digunakan pengujian hedonik (warna, aroma, rasa, dan penerimaan keseluruhan) dan pengujian skor (aroma dan rasa) (Soekarto, 1990).

\section{HASIL DAN PEMBAHASAN}

\section{Hasil Analisis Teh Celup Wangi Daun Putri Malu}

Nilai rata-rata kadar air, kadar ekstrak dalam air, total fenol, total flavonoid, dan aktivitas antioksidan berdasarkan nilai $\mathrm{IC}_{50}$ dari perbandingan daun putri malu dan bunga melati dapat dilihat pada Tabel 1.

\section{Kadar Air}

Hasil sidik ragam menunjukkan bahwa perbandingan daun putri malu dan bunga melati berpengaruh nyata $(\mathrm{P}<0,05)$ terhadap kadar air teh celup wangi daun putri malu. Berdasarkan Tabel 1, kadar air tertinggi terdapat pada perlakuan P4 (40\% daun putri malu: $60 \%$ bunga melati) yaitu sebesar $13,61 \%$, sedangkan kadar air terendah terdapat pada perlakuan P0 (100\% daun putri malu : bunga melati $0 \%$ ) yaitu sebesar 7,89\%.

Tabel 1 menunjukkan terjadi peningkatan kadar air seiring dengan meningkatnya jumlah bunga melati. Peningkatan kadar air teh celup wangi disebabkan karena adanya penambahan bunga melati dalam bentuk segar yang memiliki kadar air tinggi. Kadar air bunga melati yang ditambahkan pada teh celup wangi sebesar $65,74 \%$, sedangkan kadar air perlakuan P0 (100\% daun putri malu : 0\% bunga melati) sebesar 7,89\%. Perbedaan rasio daun putri malu dan bunga melati menghasilkan kadar air teh wangi celup yang berbeda pula. Semakin meningkatnya perbandingan bunga melati akan menghasilkan teh celup wangi daun putri malu dengan kadar air yang semakin tinggi. Hal ini sesuai dengan Rizqi (2014), tentang formulasi teh daun sukun penambahan kayu manis dan bunga melati, dimana penambahan bunga melati menghasilkan kadar air teh daun sukun yang lebih tinggi dibandingkan penambahan kayu manis.

Berdasarkan hasil penelitian pada perlakuan P4 (40\% daun putri malu : 60\% bunga melati) 
menghasilkan kadar air tertinggi yaitu sebesar 13,61\%. Kadar air yang ditetapkan oleh SNI pada teh hijau celup yaitu maksimal 10\%. Perlakuan P0 (100\% daun putri malu : $0 \%$ bunga melati) dan P1 (85\% daun putri malu : $15 \%$ bunga melati) menghasilkan kadar air yang sesuai dengan SNI, sedangkan perlakuan P2 (70\% daun putri malu : $30 \%$ bunga melati), $\mathrm{P} 3$ (55\% daun putri malu : $45 \%$ bunga melati), dan P4 (40\% daun putri malu : 60\% bunga melati) menghasilkan kadar air yang melebihi standar SNI.

Tabel 1. Nilai rata-rata kadar air, kadar ekstrak dalam air, total fenol, total flavonoid, dan aktivitas antioksidan $\mathrm{IC}_{50}$ dari teh celup wangi daun putri malu.

\begin{tabular}{cccccc}
\hline $\begin{array}{c}\text { Perbandingan Daun } \\
\text { Putri Malu dan } \\
\text { Bunga Melati }\end{array}$ & $\begin{array}{c}\text { Kadar Air } \\
(\% \mathrm{bb})\end{array}$ & $\begin{array}{c}\text { Kadar Ekstrak } \\
\text { dalam Air } \\
(\% \mathrm{bb})\end{array}$ & $\begin{array}{c}\text { Total Fenol } \\
(\mathrm{mgGAE} / \mathrm{g})\end{array}$ & $\begin{array}{c}\text { Total } \\
\text { Flavonoid } \\
(\mathrm{mgQE} / \mathrm{g})\end{array}$ & $\mathrm{IC}_{50}(\mathrm{ppm})$ \\
\hline P0 $(100 \%: 0 \%)$ & $7,89 \pm 0,39^{\mathrm{e}}$ & $20,01 \pm 0,61^{\mathrm{d}}$ & $4,42 \pm 0,11^{\mathrm{a}}$ & $1,17 \pm 0,01^{\mathrm{a}}$ & $112,04 \pm 1,71^{\mathrm{c}}$ \\
P1 $(85 \%: 15 \%)$ & $10,28 \pm 0,05^{\mathrm{d}}$ & $21,60 \pm 0,24^{\mathrm{c}}$ & $4,09 \pm 0,05^{\mathrm{b}}$ & $1,10 \pm 0,01^{\mathrm{b}}$ & $117,52 \pm 3,23^{\mathrm{c}}$ \\
P2 (70\%:30\%) & $10,97 \pm 0,11^{\mathrm{c}}$ & $22,59 \pm 0,18^{\mathrm{b}}$ & $3,70 \pm 0,11^{\mathrm{c}}$ & $1,05 \pm 0,02^{\mathrm{c}}$ & $128,73 \pm 4,33^{\mathrm{b}}$ \\
P3 (55\%:45\%) & $12,41 \pm 0,32^{\mathrm{b}}$ & $23,27 \pm 0,20^{\mathrm{b}}$ & $3,49 \pm 0,02^{\mathrm{b}}$ & $0,98 \pm 0,01^{\mathrm{d}}$ & $133,80 \pm 1,56^{\mathrm{b}}$ \\
P4 (40\%:60\%) & $13,61 \pm 0,13^{\mathrm{a}}$ & $25,40 \pm 0,78^{\mathrm{a}}$ & $3,21 \pm 0,10^{\mathrm{e}}$ & $0,95 \pm 0,05^{\mathrm{e}}$ & $142,22 \pm 5,53^{\mathrm{a}}$ \\
\hline
\end{tabular}

Keterangan: Nilai rata-rata \pm standar deviasi $(\mathrm{n}=3)$. Nilai rata-rata yang diikuti oleh huruf yang sama pada kolom yang sama menunjukkan perlakuan berbeda tidak nyata $(\mathrm{P}>0,05)$.

\section{Kadar Ekstrak dalam Air}

Hasil sidik ragam menunjukkan bahwa perbandingan daun putri malu dan bunga melati berpengaruh nyata $(\mathrm{P}<0,05)$ terhadap kadar ekstrak dalam air teh celup wangi daun putri malu. Berdasarkan data pada Tabel 1, diketahui kadar ekstrak dalam air tertinggi terdapat pada perlakuan P4 (40\% daun putri malu : 60\% bunga melati) yakni sebesar $25,40 \%$, sedangkan kadar ekstrak dalam air terendah terdapat pada P0 (100\% daun putri malu : 0\% bunga melati) yakni sebesar 20,01\%. Kadar sari larut air adalah metode kuantitatif untuk jumlah kandungan senyawa dalam simplisia yang mampu terlarut dalam pelarut air (Febrianti et al., 2019).

Hasil penelitian menunjukkan terjadi peningkatan pada kadar ekstrak dalam air teh celup wangi daun putri malu seiring dengan meningkatnya perbandingan bunga melati. Hasil uji skrining fitokimia bunga melati menunjukkan adanya senyawa benzil alkohol, flavonoid, saponin, dan tanin (Hidayah, et al., 2010). Senyawa-senyawa tersebut bersifat polar sehingga dapat terlarut dalam air. Hal tersebut menyebabkan terjadi peningkatan kadar ekstrak dalam air seiring dengan meningkatnya perbandingan bunga melati dan berkurangnya perbandingan daun putri malu pada setiap perlakuan. Kadar ekstrak dalam air yang diperoleh dari penelitian ini sudah sesuai dengan standar Farmakope Herbal Indonesia tentang kadar ekstrak dalam air simplisia teh daun yaitu tidak kurang dari 8,4\% (Anonim, 2017).

\section{Total Fenol}

Daun putri mengandung beberapa senyawa bioaktif seperti total fenol sebesar 42,9 mg GAE/g, total flavonoid sebesar 63,8 mg QE/g, dan kadar 
tanin sebesar 31,9 ppm (Das et al., 2014). Hasil sidik ragam menunjukkan bahwa perbandingan daun putri malu dan bunga melati berpengaruh nyata $(\mathrm{P}<0,05)$ terhadap kadar total fenol (Tabel 1$)$. Kadar total fenol tertinggi terdapat pada perlakuan P0 (100\% daun putri malu : 0\% bunga melati) sebesar 4,42 mg GAE/g, sedangkan kadar total fenol terendah pada perlukan P4 (40\% daun putri malu : $60 \%$ bunga melati) sebesar 3,21 mg GAE/g.

Tabel 1 menunjukkan kadar total fenol mengalami penurunan seiring dengan meningkatnya jumlah bunga melati. Penurunan total fenol terjadi dikarenakan kandungan total fenol bunga melati lebih rendah dibandingkan dengan total fenol daun putri malu. Total fenol bunga melati sebesar 1,01 mg GAE/g sedangkan total fenol perlakuan P0 (100\% daun putri malu : $0 \%$ bunga melati) sebesar $4,42 \mathrm{mg} \mathrm{GAE} / \mathrm{g}$. Total fenol yang menurun pada teh celup wangi daun putri malu terjadi dikarenakan terdapat penurunan senyawa fenol seiring dengan berkurangnya jumlah daun putri malu. Hal tersebut sesuai dengan penelitian Savitri et al., (2019) yang melaporkan terjadi penurunan total fenol pada teh celup dari teh hitam dan jahe merah, dimana penurunan total fenol terjadi dikarenakan fenol pada jahe merah lebih rendah dibandingkan dengan teh hitam.

\section{Total Flavonoid}

Hasil sidik ragam menunjukkan bahwa perbandingan daun putri malu dan bunga melati berpengaruh nyata $(\mathrm{P}<0,05)$ terhadap kadar total flavonoid teh celup wangi daun putri malu. Nilai rata-rata flavonoid yang dihasilkan dapat dilihat pada Tabel 1. Berdasarkan data hasil penelitian, diketahui bahwa pada perlakuan P0 (100\% daun putri malu : $0 \%$ bunga melati) menghasilkan kadar flavonoid tertinggi yaitu sebesar $1,17 \mathrm{mg} \mathrm{QE} / \mathrm{g}$, sedangkan pada perlakuan P4 (40\% daun putri malu : $60 \%$ bunga melati) menghasilkan kadar total flavonoid terendah yaitu sebesar $0,95 \mathrm{mg} \mathrm{QE} / \mathrm{g}$.

Hasil penelitian menunjukkan bahwa semakin meningkat jumlah bunga melati maka total flavonoid akan semakin menurun. Kandungan flavonoid bunga melati lebih rendah dibandingkan daun putri malu. Total flavonoid bunga melati sebesar $0,55 \mathrm{mg}$ QE/g sedangkan total flavonoid pada perlakuan P0 (100\% daun putri malu : 0\% bunga melati) sebesar $1,17 \mathrm{mg} \mathrm{QE} / \mathrm{g}$. Teh celup wangi daun putri malu mengalami penurunan total flavonoid seiring dengan berkurangnya jumlah daun putri malu. Hal tersebut sesuai dengan Budianta (2019) tentang pengaruh penambahan tepung daun sirsak pada teh hitam terhadap aktivitas antioksidan dalam minuman, bahwa penurunan total flavonoid pada seduhan teh hitam daun sirsak terjadi akibat berkurangnya jumlah teh hitam yang memiliki kandungan flavonoid yang lebih tinggi.

\section{Aktivitas Antioksidan Berdasarkan Nilai IC $_{50}$}

Pemberian perlakuan perbandingan daun putri malu dan bunga melati berpengaruh nyata $(\mathrm{P}<0,05)$ terhadap aktivitas antioksidan teh celup wangi daun putri malu. Parameter yang digunakan untuk aktivitas antioksidan dengan metode penangkapan radikal DPPH ini adalah nilai $\mathrm{IC}_{50}$ yaitu jumlah senyawa ekstrak uji yang dibutuhkan untuk mengurangi intensitas warna radikal DPPH sebesar 50\% (Zou et al., 2004). Nilai $\mathrm{IC}_{50}$ yang semakin kecil menunjukkan aktivitas antioksidan yang semakin tinggi dikarenakan jumlah bahan 
yang dibutuhkan untuk peredaman radikal bebas sebesar 50\% semakin sedikit. Berdasarkan hasil yang diperoleh dapat terlihat bahwa perlakuan P0 (100\% daun putri malu : 0\% bunga melati) menghasilkan aktivitas antioksidan tertinggi yaitu sebesar 112,04 ppm, sedangkan pada perlakuan P4 (40\% daun putri malu : $60 \%$ bunga melati) menghasilkan aktivitas antioksidan terendah yaitu sebesar $142,22 \mathrm{ppm}$. Nilai $\mathrm{IC}_{50}$ dari bunga melati pada penelitian ini sebesar 448,95 ppm.

Data pada Tabel 1 menunjukkan semakin meningkatnya jumlah bunga melati mengakibatkan aktivitas antioksidan teh daun putri malu akan mengalami penurunan. Hal tersebut dikarenakan terjadinya penurunan kadar total fenol dan total flavonoid seiring dengan meningkatnya jumlah bunga melati. Senyawa fenol dan flavonoid memiliki kontribusi linier terhadap aktivitas antioksidan (Ghasemzadeh et al., 2011). Penurunan pada kadar total fenol dan total flavonoid dapat menyebabkan penurunan aktivitas antioksidan. Hal ini juga didukung oleh penelitian Tahir et al., (2017) tentang aktivitas antioksidan minuman fungsional daun sukun dan bunga melati menggunakan metode teh wangi. Semakin meningkat jumlah bunga melati yang ditambahkan maka nilai aktivitas antioksidan minuman fungsional daun sukun akan semakin menurun.

Berdasarkan Tabel 1, teh celup wangi daun putri malu memiliki nilai $\mathrm{IC}_{50}$ berkisar antara 112,04 ppm - 142,22 ppm. Nilai tersebut dapat diartikan bahwa aktivitas antioksidan dari produk teh celup wangi daun putri malu adalah sedang. Menurut Christiani et al., (2020), nilai $\mathrm{IC}_{50}$ teh celup herbal daun putri malu sebesar 69,61 ppm, hal ini menunjukkan penambahan bunga melati menyebabkan terjadinya penurunan aktivitas antioksidan dari teh celup herbal daun putri malu.

\section{Karakteristik Sensori}

Nilai rata-rata uji skor aroma dan rasa dapat dilihat pada Tabel 2, dan nilai rata-rata uji hedonik dapat dilihat pada Tabel 3.

\section{Warna}

Hasil sidik ragam menunjukkan bahwa perbandingan daun putri malu dan bunga melati berpengaruh tidak nyata $(\mathrm{P}>0,05)$ terhadap penerimaan warna seduhan teh celup wangi daun putri malu. Nilai rata-rata yang diberikan panelis berkisar antara 5,44 - 6,08 dengan kriteria agak suka hingga suka. Seduhan teh celup wangi daun putri malu berwarna kuning kecoklatan.

Hasil sidik ragam menunjukkan bahwa perbandingan daun putri malu dan bunga melati berpengaruh nyata $(\mathrm{P}<0,05)$ terhadap penerimaan aroma (uji hedonik) teh celup wangi daun putri malu penambahan bunga melati. Penerimaan panelis terhadap aroma produk berkisar antara 4,72 - 6,00 dengan kriteria biasa hingga suka. Tabel 3 menunjukkan semakin meningkat jumlah bunga melati maka semakin tinggi nilai kesukaan panelis terhadap aroma teh celup wangi daun putri malu. Hal ini sesuai dengan penelitian yang dilakukan oleh Tahir (2017) bahwa penambahan bunga melati dapat memperbaiki serta meningkatkan daya terima panelis terhadap aroma minuman herbal daun sukun.

\section{Aroma}

Hasil sidik ragam menunjukkan bahwa perbandingan daun putri malu dan bunga melati berpengaruh nyata $(\mathrm{P}<0,05)$ terhadap penerimaan 
aroma pada uji skor seduhan teh celup wangi daun putri malu. Nilai rata-rata aroma terendah diperoleh perlakuan P0 (100\% daun putri malu : $0 \%$ bunga melati) yaitu 1,20 dengan kriteria tidak beraroma, sedangkan nilai tertinggi diperoleh perlakuan $\mathrm{P} 4$ (40\% daun putri malu : 60\% bunga melati) dengan kriteria khas melati. Tabel 2 menunjukkan semakin meningkat jumlah bunga melati maka aroma teh celup wangi semakin khas melati. Bunga melati memiliki senyawa yang dapat menghasilkan aroma harum pada teh herbal daun putri malu. Senyawa volatil yang berkontribusi memberikan aroma yang khas pada bunga melati antara lain z-jasmone, benzil asetat, indol, E-E- $\alpha$ farnesene, neurol idol, metil salisilat, linalool, dan benzil alkohol (Edris et al., 2008).

\section{Rasa}

Hasil sidik ragam menunjukkan bahwa perbandingan daun putri malu dan bunga melati berpengaruh nyata $(\mathrm{P}<0,05)$ terhadap rasa seduhan teh celup wangi daun putri malu yang diuji secara skor. Nilai rata-rata yang dihasilkan dari uji skor berkisar antara 3,40 - 3,80 dengan kriteria agak pahit. Rasa agak pahit pada seduhan diduga disebabkan oleh adanya senyawa alami pada bahan yang memiliki pengaruh terhadap rasa suatu produk. Tanin merupakan salah satu senyawa yang terkandung dalam daun putri malu. Hal ini sesuai dengan Martono (2014) yang menyatakan bahwa kandungan tanin menyebabkan berpengaruhnya terhadap rasa pahit dan sepat. Semakin bertambahnya bunga melati mampu mengurangi sedikit rasa agak pahit dari daun putri malu. Hal tersebut dikarenakan berkurangnya jumlah daun putri malu pada teh celup. Hasil sidik ragam menunjukkan bahwa bahwa perbandingan daun putri malu dan bunga melati berpengaruh nyata $(\mathrm{P}<0,05)$ terhadap kesukaan panelis pada rasa seduhan teh celup wangi daun putri malu. Nilai rata-rata yang diberikan oleh panelis berkisar antara 3,92 (agak tidak suka) - 5,56 (suka). Hal tersebut menunjukkan bahwa peningkatan jumlah bunga melati mampu meningkatkan daya terima panelis terhadap rasa seduhan teh celup wangi daun putri malu. Hal tersebut sesuai dengan Arief dan Anggoro (2008), kandungan senyawa kimia pada bunga dan daun melati menimbulkan rasa agak manis dan bersifat sejuk.

Tabel 3. Nilai rata-rata kesukaan terhadap aroma, warna, rasa, dan penerimaan keseluruhan teh celup wangi daun putri malu.

\begin{tabular}{ccccccc}
\hline $\begin{array}{c}\text { Perbandingan Daun } \\
\text { Putri Malu dan } \\
\text { Bunga Melati }\end{array}$ & Aroma & Warna & Rasa & $\begin{array}{c}\text { Penerimaan } \\
\text { Keseluruhan }\end{array}$ & Aroma & Rasa \\
\hline P0 $(100 \%: 0 \%)$ & $4,72 \pm 1,17^{\mathrm{c}}$ & $5,44 \pm 1,00^{\mathrm{b}}$ & $3,92 \pm 1,07^{\mathrm{d}}$ & $4,28 \pm 1,10^{\mathrm{d}}$ & $1,20 \pm 0,57^{\mathrm{d}}$ & $3,40 \pm 0,64^{\mathrm{b}}$ \\
P1 $(85 \%: 15 \%)$ & $5,04 \pm 1,06^{\mathrm{bc}}$ & $5,84 \pm 0,85^{\mathrm{ab}}$ & $4,48 \pm 1,04^{\mathrm{cd}}$ & $4,72 \pm 1,06^{\mathrm{cd}}$ & $1,84 \pm 0,62^{\mathrm{c}}$ & $3,36 \pm 0,64^{\mathrm{b}}$ \\
P2 $(70 \%: 30 \%)$ & $5,40 \pm 1,08^{\mathrm{ab}}$ & $5,80 \pm 0,91^{\mathrm{ab}}$ & $4,88 \pm 0,92^{\mathrm{bc}}$ & $5,16 \pm 0,80^{\mathrm{bc}}$ & $2,16 \pm 0,47^{\mathrm{c}}$ & $3,40 \pm 0,86^{\mathrm{b}}$ \\
P3 $(55 \%: 45 \%)$ & $5,68 \pm 0,98^{\mathrm{a}}$ & $6,08 \pm 0,70^{\mathrm{a}}$ & $5,32 \pm 0,98^{\mathrm{ab}}$ & $5,60 \pm 0,70^{\mathrm{a}}$ & $2,52 \pm 0,65^{\mathrm{b}}$ & $3,80 \pm 0,40^{\mathrm{a}}$ \\
P4 (40\%:60\%) & $6,00 \pm 0,91^{\mathrm{a}}$ & $5,88 \pm 0,92^{\mathrm{ab}}$ & $5,56 \pm 0,96^{\mathrm{a}}$ & $6,08 \pm 0,70^{\mathrm{a}}$ & $3,36 \pm 0,57^{\mathrm{a}}$ & $3,80 \pm 0,64^{\mathrm{a}}$ \\
\hline
\end{tabular}

Keterangan: Nilai rata-rata \pm standar deviasi $(\mathrm{n}=3)$. Nilai rata-rata yang diikuti oleh huruf yang sama pada kolom yang sama menunjukkan perlakuan berbeda tidak nyata $(\mathrm{P}>0,05)$.

Kriteria hedonik: 7 (Sangat Suka); 6 (Suka); 5 (Agak Suka); 4 (Biasa); 3 (Agak Tidak Suka); 2 (Tidak Suka); 1 (Sangat Tidak Suka).

Kriteria untuk aroma: 4 (Sangat Khas Melati); 3 (Khas Melati); 2 (Agak Khas Melati); 1 (Tidak Beraroma). 
Kriteria untuk rasa: 4 (Tidak Pahit); 3 (Agak Pahit); 2 (Pahit); 1 (Sangat Pahit)

\section{Penerimaan Keseluruhan}

Hasil sidik ragam menunjukkan bahwa perbandingan daun putri malu dan bunga melati berpengaruh nyata $(\mathrm{P}<0,05)$ terhadap penerimaan keseluruhan seduhan teh celup wangi daun putri malu. Nilai rata-rata uji hedonik terhadap penerimaan keseluruhan seduhan teh celup wangi daun putri malu berkisar antara 4,28 (biasa) hingga 6,08 (suka). Data tersebut menunjukkan semakin meningkat perbandingan bunga melati pada pembuatan teh celup wangi daun putri malu dapat meningkatkan daya terima panelis terhadap penerimaan keseluruhan produk. Penerimaan keseluruhan teh celup wangi daun putri malu dipengaruhi oleh berbagai faktor seperti warna, aroma, dan rasa.

\section{KESIMPULAN DAN SARAN}

\section{Kesimpulan}

Perbandingan daun putri malu dan bunga melati berpengaruh nyata $(\mathrm{P}<0,05)$ terhadap kadar air, kadar ekstrak dalam air, total fenol, total flavonoid, aktivitas antioksidan berdasarkan nilai $\mathrm{IC}_{50}$, aroma (uji kesukaan dan skor), rasa (uji kesukaan dan skor), dan penerimaan keseluruhan. Perbandingan $70 \%$ daun putri malu dan $30 \%$ bunga melati menghasilkan teh celup wangi dengan karakteristik terbaik dengan kriteria kadar air 10,97\%, kadar ekstrak dalam air $22,59 \%$, total fenol $3,70 \mathrm{mg}$ $\mathrm{GAE} / \mathrm{g}$, total flavonoid $1,05 \mathrm{mg} \mathrm{QE} / \mathrm{g}$, nilai $\mathrm{IC}_{50}$ sebesar 128,73 ppm, serta sifat sensori warna agak suka, aroma agak khas melati dan agak suka, rasa agak pahit dan agak suka, dan penerimaan keseluruhan agak suka.

\section{Saran}

Pembuatan teh celup wangi daun putri malu dapat dilakukan dengan perbandingan $70 \%$ daun putri malu dan $30 \%$ bunga melati.

\section{DAFTAR PUSTAKA}

AOAC. (2005). Official Methods of Analysis of the Association of Official Analytical Chemists. Association of Official Analytical Chemist, Maryland.

Ahmad, H., S. Sehgal, A. Mishra, dan R. Gupta. (2012). Mimosa pudica L. (Laajvanti): an overview. Journal Pharmacognosy. 6(12):115-124.

Anonim. (1996). Standar Nasional Indonesia (SNI) Tentang Teh Celup. 01-4324-1996. SNI, Jakarta.

Anonim. (2017). Farmakope Herbal Indonesia Edisi II. Kementerian Kesehatan Republik Indonesia, Jakarta.

Arifan, F., S. Winarni, G. Handoyo, A. Nurdiana, A.N. Rahma and S. Risdiyanti. (2018). An analysis of antioxidants, organoleptics and hedonics with variations of boiling time in Jasmine tea and Jasmine root tea a study on Kaliprau, Pemalang. The $7^{\text {th }}$ International Seminar on New Paradigm and Innovation on Natural science and Its Application, Semarang: 17 Oktober 2017.

Budianta, T.D.W.B., P.S. Widyawati dan V. Haditanojo. (2019). Pengaruh perbedaan proporsi tepung daun sirsak (Annona murcicata L.) dan teh hitam terhadap aktivtias antioksidan dalam minuman. Jurnal Teknologi Pangan dan Gizi. 18(1):33-43.

Christiani, E.A., I.N.K. Putra., dan I.P. Suparthana. Pengaruh variasi suhu dan waktu pengeringan terhadap sifat kimia dan sensori teh celup herbal daun putri malu (Mimosa pudica Linn.). Skripsi S1. Tidak dipublikasikan. Universitas Udayana, Bali.

Dalimartha, S. (2008). 1001 Resep Herbal. Swadaya, Jakarta.

Das, K., M. Yasin, N.U. Mahbub, M.S. Islam and N. Mahbuba. (2014). Evaluation of antioxidant and cytoxic activity of methanolic extract of Mimosa pudica leaves. The Pharma Innovation-Journal 3(4): 32-36.

Edris. A., C. Franz, and R. Chizzola. (2008). Isolation and characterization of the volatile aroma compounds from the concrete headspace and the absolute of Jasminum sambac (L.) Ait. (Oleaceae) 
flowers grown in Egypt. Journal Eur Food Research Technology. 226(1):621-626.

Febrianti, D.R., Mahrita, N. Ariani, A.M.P. Putra, dan Noorcahyati. (2019). Uji kadar sari larut air dan kadar sari larut etanol daun kumpai mahung (Eupathorium inulifolium H.B.\&K). Jurnal Pharmascience. 6(2):19-24.

Ghasemzadeh, A., V. Omidvar and H.Z.E. Jaafar. (2012). Polyphenolic content and their antioxidant activity in leaf extract of sweet potato (Ipomoea batatas). Journal of Medicinal Plant Research 6(15):2971-2976.

Hanani, E., A. Mun'im, dan R. Sekarini. (2005). Identifikasi senyawa antioksidan dalam spons Callyspongia sp dari kepulauan Seribu. Majalah Ilmu Kefarmasian. 2(3):127-133.

Handayani, E.S., M. Hubeis, dan N.S. Palupi. (2011). Kajian perilaku konsumen terhadap strategi pemasaran teh herbal di kota Bogor. Jurnal Manajemen IKM. 6(2):143-151.

Hidayah, N., A. Herawati, dan A. Habibi. (2010). Identifikasi kandungan fitokimia ekstrak bunga melati (Jasminum sambac (L.) Ait) komoditas lokal yang berpotensi sebagai antilarvasida. Dinamika Kesehatan Jurnal Kebidanan dan Keperawatan. 10(1):476-483.

Inti, K. (2008). Teh Herbal Minuman Berkhasiat Pemulih Kesehatan. Gramedia Pustaka Utama, Jakarta.

Kunhachan, P., C. Banchonglikitkul, T. Kajsongkram, A. Khayungarnnawee and W. Leelamanit. (2012). Chemical composition, toxicity, and vasodilatation effect of the flowers extract of Jasminum sambac (L.) Ait. "G. Duke of Tuscany". Journal of Evidence-Based Complementary and Alternative Medicine. 2012(4):1-7.

Martono, B. dan R.T. Setiyono. (2014). Skrining fitokimia enam genotipe teh. Jurnal Tanaman Industri dan Penyegar. 1(2):63-68.

Molyneux, P. (2004). The use of the stable free radical diphenylpicryl-hydrazyl (DPPH) for estimating antioxidant activity. Journal Science Technology. 26(2):211-219.

Narasimhan, G., K. Johnson, and C. Krishnan. (2014). Mimosa pudica Linn- a shyness princess: a review of its plant movement, active constituents, uses and pharmacological activity. International Journal of Pharmaceutical Sciences and Research. 5(12):5104-5118.

Pal, P., S. Datta, H. Basnett, B. Shrestha and J.P. Mohanty. (2015). Phytochemical analysis of the whole plant of Mimosa pudica (Linn.). Universal Journal of Pharmaceutical Sciences and Research. $1(1): 1-9$.

Ray, H., N. Bhattacharyya, A. Ghosh, B. Tudu, R. Bandyopadhyay, A. Ghosh, S. Parua, and S. Majumdar. (2016). Identification of optimum blossoming stage of Jasminum sambac Ait. flowers for concrete extraction using electronic nose. National Academy of Agriculture Science. 33(2):579-589.

Rahayu, W.P., S. Nurosiyah, dan R. Widyanto. Evaluasi Sensori Edisi 2. Universitas Terbuka, Tangerang Selatan.

Rizqi, M.M. dan A. Sulaeman. (2014). Formulasi teh daun sukun (Artocarpus altilis) dengan penambahan kayu manis dan melati sebagai minuman fungsional. Skripsi S1. Tidak dipublikasikan. Institut Pertanian Bogor, Bogor.

Sakanaka, S., Y. Tachibana, and Y. Okada. (2005). Preparation and antioxidant properties of extracts of Japanese persimmon leaf tea (kakinoha-cha). Food Chemistry. 89(4):569-575.

Savitri, K.A.M., I.W.R. Widarta, dan A.A.G.N.A Jambe. (2019). Pengaruh perbandingan teh hitam (Camellia sinsensis) dan jahe merah (Zingiber officinale var. Rubrum) terhadap karakteristik teh celup. Jurnal Ilmu dan Teknologi Pangan. $8(4): 419-429$.

Setyamidjaja, D. (2000). Teh: Budidaya dan Pengolahan Pascapanen. Kanisisus, Yogyakarta.

Shahriar, M., U. Aziz, R. Akhter, and M.A. Bhuiyan. 2014. In vivo pharmalogical investigation of Mimosa pudica Linn. International Journal of Pharmaceutical Science. 6(2):66-69.

Soekarto. (1990). Penilaian Organoleptik Untuk Industri Pangan dan Hasil Pertanian. Bhatara Aksara, Jakarta.

Tahir, M.M., Zainal and Darma. (2017). Aktivitas antioksidan dan karakteristik organoleptik minuman daun sukun (Artocarpus Altilis) dengan penambahan bunga melati (Jasminum sambac Ait.). Journal of Agritech Science. 1(2):1-11.

Topuz, A., C. Dincer, M. Torun, I. Tontul, H.S. Nadeem, A. Haznedar and F. Özdemir. (2014). Physicochemical properties of turkish green tea powder: effects of shooting period, shading, and clone. Turkish Journal of Agriculture and Forestry 38:233-241.

Varnika, S., S. Ashish, and A. Imran. (2012). A review on ethnomedical and traditional uses of Mimosa pudica (chui-mui). International Research Journal of Pharmacy. 3(2):41-44.

Winarno, F.G. (2008). Ilmu Pangan dan Gizi. PT. Gramedia Pustaka Utama, Jakarta.

Zhang, J., K. Yuan, W. Zhou, J. Zhou and P. Yang. (2010). Studies on the active components and antioxidant activities of the extracts of Mimosa pudica Linn. from southern China. Pharmacognosy Magazine. 7(25):35-39.

Zou, Y., Y. Lau, and D. Wei. (2004). Antioxidant activity of flavonoid-rich extract of Hypericum perforatum L. in vitro. Journal of Agricultural and Food Chemistry. 52(16):5032-5039. 